\title{
Kala Dobosz
}

Katedra Metod i Technik Badan Społecznych, Uniwersytet Łódzki E-MAIL: kairi.dobosz@gmail.com ORCID: oooo-0oo2-3894-3747

\section{Droga, której nie znamy - opowieści uchodźcze}

\author{
Before beginning a study of war, \\ a researcher must decide where \\ to look for it.
}

Carolyn Nordstrom

\begin{abstract}
STRESZCZENIE
Prezentowana opowieść, którą Czytelniczka i Czytelnik znajdą w tekście (gdy ja, badaczka, zamilknę), pochodzi z wywiadów zebranych w czasie badań prowadzonych przeze mnie w Holandii w 2013 roku. Wybrany wówczas problem badawczy - zagadnienie tożsamości Tamilów ze Sri Lanki w Holandii - postanowiłam eksplorować posługując się zmodyfikowaną wersją metody biograficznej, która coraz częściej wykorzystywana jest w badaniach socjologicznych. Taki model analizy jest dziś również częsty w studiach nad procesami migracji, a zwłaszcza w badaniach problemu uchodźstwa. Posługując się tą metodą przedstawiam w części analitycznej cykl życia uchodźcy oparty na schemacie rytuałów przejścia Arnolda van Gennepa. Wykorzystuję więc model zaczerpnięty z badań antropologicznych, a mianowicie schemat przechodzenia przez jednostki przez określone stadia w swoim rozwoju i w procesie społecznego funkcjonowania. Po pierwszej części, gdzie w zarysie prezentuję metodologię badania oraz główne założenia teoretyczne, zamieszcza pierwszoosobową narrację jednej z osób, która ze Sri Lanki wyjechała, a jej życie splecione było nierozerwalnie z tamtejszą prawie 3o-letnią wojną domową.
\end{abstract}

SŁOWA KLUCzowe: wojna domowa w Sri Lance, metoda biograficzna, fazy życia uchodźcy, strategia narracyjna

\section{Wprowadzenie}

Ślady naszych stóp opowiadają o nas ciekawe historie. Idziemy dokądś, wracamy stamtąd, znów gdzieś się udajemy. Czasem gubimy trasę, jak wątek wypowiedzi czy myśli. Czasem w ogóle zmienia się kierunek naszej podróży. Jeśli nasze podróże są dobrowolne, to jesteśmy szczęściarzami. Moja opowieść zawierać będzie jednak opowieści tych mniej szczęśliwych. Tych, dla których podróż okazała się czymś koniecznym - nawet jeśli sami się na nią decydowali. 
Przemieszczenia, którymi chcę się tu zająć miały swój punkt startowy w położonej na Oceanie Indyjskim Socjalistyczno-Demokratycznej Republiki Sri Lanki. Głosem tych, którzy opuścili Sri Lankę, gdzie przez okres prawie trzydziestu lat (1983-2009) toczyła się wojna, opowiem o doświadczeniu uchodźczym. W Sri Lance separatystyczna organizacja Tygrysy Wyzwolenia Tamilskiego Illamu (ang. Liberation Tigers of Tamil Eelam, w skrócie LTTE, nazywana powszechnie Tamilskimi Tygrysami) walczyła o utworzenie niezależnego państwa Eelam (tamil. ஈழம், trl. īlam trb. Illam/Eezham). Skutkiem tego była długa i wyniszczająca wojna. Najczęściej przywoływanymi w pracach naukowych pojęciami są: terroryzm, konflikt etniczny oraz nacjonalizm diaspory, czy inaczej „nacjonalizm na odległośc” (long-distance nationalism), ponieważ spora część tamilskich Lankijczyków i Lankijek z wyspy wyjechała, ale o swoim kraju nie zapomniała. O nich będzie wiele w przywoływanej w niniejszym tekście opowieści.

\section{Doświadczenie uchodźstwa}

Uchodźstwo, choć należy do tzw. forced migration, pociąga za sobą także dobrowolne migracje, naturalne jest bowiem, że rodziny pragną się łączyć. Nierzadko uciekinierzy z uwagi na uzasadnione obawy przed torturami, uwięzieniem, czy nawet śmiercią nie mogą powrócić do kraju, w którym się urodzili, ale chcą żyć ze swoimi rodzinami. Tworzą się więc wspólnoty (narodowe czy etniczne) w rozproszeniu, a więc diaspory. Szacuje się, że dziś diaspora Tamilów ze Sri Lanki liczy ok. 3 milionów, przy czym liczba Tamilów i Tamilek wraz z tymi zamieszkującymi południowe Indie wynosi łącznie ok. 80 milionów (Sivasupramaniam, 200o). Czyni to społeczność Tamilów silną grupą nacisku politycznego. Nie będzie więc nadużyciem stwierdzenie, iż studium tego przypadku pozwoli nam przybliżyć się do zrozumienia procesów zachodzących na całym świecie.

Historia ta jest splotem czynników egzogennych i endogennych, które w ostatniej fazie wojny doprowadziły nie tylko do śmierci 40, a może nawet 70 tysięcy Lankijek i Lankijczyków (w większości Tamilek i Tamilów), ale też „Zniknięcia” bez śladu wielu innych. „Znikanie” nie zakończyło się jednak wraz z końcem wojny. Już w okresie oficjalnego pokoju w nieznanych okolicznościach „zniknęły” tysiące osób. W 2012 roku ONZ zaraportowało, że „brakuje” 70 tysięcy mieszkańców Północy (biskup Mannaru podawał liczbę 147 tysięcy zaginionych w prowincji Wanni). W czasie wojny i zaraz po niej ludzie byli porywani przez białe furgonetki (stąd pochodzi angielski czasownik whitevanned). W sierpniu 2014 roku prawie 20 tysięcy osób (w tym ponad 5500 członków rodzin zaginionego personelu wojskowego) podpisało 
petycję w sprawie uzyskania informacji na temat zaginionych krewnych (Mittal, 2015, s. 4).

Literatura poświęcona Sri Lance jest niezmiernie bogata. Lankijska przyroda zachwyca. Zafascynowany Cejlonem francuski misjonarz pisał: „Sri Lanka - Święta Lanka, opiewają cię poeci i mówcy! W jakiejś tkliwej zgodzie wszystkie ludy starożytne sławią przepyszną urodę Cejlonu" (Duchaussois, 1931, s. 1). Jednak to właśnie doświadczenie prawie trzech dekad wojny przywiodło mnie do tego kraju. Z początkowego zainteresowania tylko jedną stroną konfliktu powstawały moje kolejne prace poświęcone Sri Lance. Badania zainspirowały w 2009 roku byłego konsula RP w Indiach Marka Moronia do wykładów prowadzonych w Katedrze Porównawczych Studiów Cywilizacji Uniwersytetu Jagiellońskiego, poświęconych Azji Południowej i Południowo-Wschodniej. Spośród omawianych przez niego rozmaitych ruchów politycznych i działań partyzantek, tamilski i syngalesko-buddyjski wydały mi się najbardziej dostępne. Początkowo analizowałam wyłącznie retorykę stosowaną przez tamilskich nacjonalistów. Chciałam zrozumieć, kim właściwie owi separatyści są i jakie mają techniki działania, jakie mogą być potencjalne tego skutki. Wyjazd na Sri Lankę nie wchodził wówczas w rachubę, m.in. z powodów bezpieczeństwa i nikłego doświadczenia w prowadzeniu badań terenowych. Okazało się jednak, że walczący o Eelam Tamilowie już od lat 90. swoją aktywność polityczną prowadzili za pomocą Internetu 2. Patrzyłam wówczas „z Północy”, w podwójnym znaczeniu - z perspektywy Północy w klasycznym ujęciu globalnych zależności oraz z perspektywy materialnej przestrzeni wyznaczającej społeczno-polityczne zależności w tym kraju, a więc północnej jego części. Początkowo - błędnie - widziałam ją wyłącznie w ramie konfliktu pomiędzy Tamilami i Syngalezami. Nie będzie to jednak moja opowieść, a opowieść jednej z wielu osób, które spotkałam na swojej drodze badawczej.

\section{Metoda biograficzna}

Prezentowana opowieść, którą Czytelniczka i Czytelnik znajdą w dalszej części tekstu (gdy ja, badaczka, zamilknę) pochodzi z wywiadów zebranych w czasie badań prowadzonych przeze mnie w Holandii w 2013 roku. Wybrany przeze mnie wówczas problem badawczy - zagadnienie tożsamości Tamilów ze Sri Lanki w Holandii - postanowiłam zbadać posługując się zmodyfikowaną wersją metody biograficznej. Odpowiednim podejściem badawczym w niniejszym przedmiocie byłaby także metoda monografii problemowej, niestety ze względu na ograniczenia czasowe niemożliwe było jej stworzenie. Pomimo tej trudności, starałam się jednak włączyć do tego projektu działa- 
nia nakierowane na osiągnięcie nadrzędnego celu, jaki przyświeca tego typu badaniom, a więc opisanie stanu badanej społeczności w określonym czasie. Niemożliwe było określenie dynamiki przemian społecznych zachodzących w jej obrębie (Wierzbicki, 1971, s. 299), jednak przeprowadzona przeze mnie analiza może zostać potraktowana jako określenie stanu początkowego, który jest warunkiem identyfikacji przemian społecznych - zwłaszcza jeśli chodzi o badania porównawcze I i II generacji tamilskich migrantów. W uproszczeniu, jest to charakterystyka „stanu pamięci” członków tamilskiej diaspory w znaczącym politycznie momencie - do września 2013 roku nie było mowy o jakiejkolwiek niezależności Północnej Prowincji, która dla lankijskich Tamilów jest dziś pozostałością po quasi-państwie Eelam z czasów walki Tamilskich Tygrysów. Z pewnością kolejne badania umożliwią określenie z perspektywy czasu skutki polityczne demokratycznych z założenia wyborów na tym terenie i ich wpływ na zbiorową świadomość Tamilów poza granicami kraju. Tymczasem posłużyłam się metodą biograficzną, która coraz częściej wykorzystywana jest w badaniach socjologicznych. Taki model analizy jest dziś również częsty w studiach nad procesami migracji, a zwłaszcza w badaniach problemu uchodźstwa. Posługując się tą metodą przedstawiam w części analitycznej cykl życia uchodźcy w oparciu o schemat rytuałów przejścia Arnolda van Gennepa.

Istotą metody biograficznej stosowanej w badaniach socjologicznych jest wykorzystywanie relacji jednostek o ich uczestnictwie w zdarzeniach i procesach, które stanowią przedmiot badań do opisu tych procesów i postawienia hipotez wyjaśniających (patrz:. Valenta, 2010). Jak podaje Jan Szczepański, metoda ta, inaczej zwana metodą dokumentów ludzkich, pojawiła się w socjologii w momencie, gdy socjologowie zarzucili projekt tworzenia „wielkich syntez wyjaśniających istotę społeczeństwa” oraz ustalania ogólnych prawideł rządzących życiem i rozwojem ludzkości kierując się w stronę badań empirycznych nad wybranymi aspektami faktów społecznych (Szczepański, 1971, s. 577-578). Zaczęto więc, prócz opisów zewnętrznych cech wybranych społeczności, podejmować próby wyjaśniania postaw psychicznych i ich zmian w kontekście różnych struktur społecznych. Za ojców tej metody uznaje się Floriana Znanieckiego i Williama Thomasa, autorów pięciotomowego dzieła publikowanego w latach 1918-1920. Jednak zasadniczy wkład w stosowana dziś w Polsce (głównie w kręgu łódzkich badaczy i badaczek biograficznych) formę tej metody wniósł niemiecki socjolog Fritz Schütze (2012).

Schütze w sposób szczegółowy zaprezentował metodę analizy wywiadu narracyjnego $\mathrm{w}$ jej wymiarze formalnym i treściowym. Tym samym dostarczył on badaczowi instrumentów intersubiektywnej samokontroli procesu 
badawczego (Kaźmierska, 2012). Jego podejście badawcze wyraźnie różni się od perspektywy symbolicznego interakcjonizmu w kluczowym punkcie - dla Schützego istotne było odzwierciedlenie „zdynamizowanej retrospekcji”, podczas gdy interakcjoniści dążyli do „chwytania fenomenu społecznego in actu". Stosowana przez kontynuatorów Schützego technika wywiadu narracyjnego ma jednak pewne słabości, które uniemożliwiły w niniejszym badaniu jej pełnego wykorzystania. Przede wszystkim podstawowym założeniem teoretycznym tej metody jest teza o „homologii między strukturą organizacji doświadczenia wydarzeń w życiu a strukturą autobiograficznej narracji”. Przyczyną była bariera językowa - język angielski zarówno dla mnie, jak i narratorów jest drugim językiem, przy czym większość z nich aktualnie częściej posługuje się językiem holenderskim. W związku z tym przyjęłam, iż narratorzy będą posługiwać się w swoich opowieściach utartymi formułami zdaniowymi, co zmniejsza wartość formalnego opisu ich wypowiedzi. Drugim ograniczeniem była trudność w wywołaniu spontanicznej, a więc niezakłóconej interwencją badacza narracji. Po przeprowadzeniu dwóch pilotażowych wywiadów postanowiłam ustalić jeden schemat wywiadu, który miał wskazywać kierunki narracji zorientowane na kwestie doświadczenia wojny i uchodźctwa na szerszym tle życia społeczno-politycznego Sri Lanki. Segmenty narracji zostały przeze mnie z góry określone zgodnie z przyjętym modelem faz życia uchodźcy. Były to więc wywiady półustrukturyzowane, w których moje pytania zachęcały do opowieści o kolejnych etapach życia, od wczesnego dzieciństwa i życia na Sri Lance, aż do momentu, w którym toczył się wywiad. Niemniej jednak, zgodnie ze wskazaniami Schützego korzystałam na etapie analitycznej abstrakcji z elementu techniki, jakim było wyróżnianie w opowieściach narratorów fragmentów narracyjnych, opisowych i argumentacyjnych. Pozwoliły one wyłonić tzw. kategorie swoiste i kategorie ogólne, które stanowiły punkt wyjścia w budowie modelu teoretycznego. Zachowałam również jego podstawowe założenie o możliwości porównywania jednostkowych losów biograficznych jako z jednej strony swoistych form przebiegu ludzkiego życia, a z drugiej wyrazu ich uwikłania w zbiorowe procesy społeczne.

\section{Cykl życia uchodźcy}

Zakładam, że w życiu uchodźcy występują pewne kluczowe momenty kształtujące ich tożsamość, która sytuuje się na przecięciu doświadczeń jednostkowych i kolektywnych ofiar wojny. W analizie narracji wojennych wyszczególnia się najczęściej tzw. trajektorie cierpienia jednostkowego lub kolektywnego. Są to sytuacje, w których jednostka traci poczucie kontroli 
nad swoim życiem, i to zewnętrzne zdarzenia kształtują od tej pory jego bieg. Przykładem tej pierwszej może być np. zmaganie się z ciężką chorobą, a najpowszechniejszym przypadkiem trajektorii cierpienia kolektywnego jest doświadczenie wojny i przymusowego uchodźstwa. Osoby takie zostają „wyzute z ziemi” - nie tylko tracą posiadaną wcześniej ziemię w sensie materialnym, ale z konieczności opuszczają „własną ziemię” w znaczeniu własnego państwa.

Robert Y.C. Young, profesor filologii angielskiej i teorii krytycznej w Oxfordzie, dokonując systematycznego przeglądu politycznych, społecznych i kulturowych konsekwencji procesu dekolonizacji, wskazał m.in. na pojawienie się w jego wyniku aż 20 milionów uchodźców na świecie. Stali się oni współczesnymi nomadami w rozumieniu Gillesa Dleuze’a i Felixa Guattariego, zdaniem których „nomada to osoba najskuteczniej opierająca się kontrolnym instytucjom państwa" (za: Young, 2012). Nomada ciągle przemierza kolejne kraje nie posiadając jednego „stałego miejsca”, które mógłby uznać za „swoje”. Jak wyjaśnię wykorzystując koncepcję rytów przejścia Arnolda van Gennepa, lankijscy uchodźcy nie stają się nomadami w takim znaczeniu. Pomimo, iż po osiedleniu się poza Sri Lanką zazwyczaj wiele podróżują, są to jednak podróże $z$ uwagi na osobiste cele, nic nie świadczy więc za tym, że zostają oni uwięzieni jako grupa w świecie nomadyczności. W sytuacji, gdy uchodźca przymusowy przechodzi kolejne stadia stawania się i bycia uchodźcą, przekraczając fazy wyłączenia, liminalną i ostatecznie fazę włączenia asymilując się ze społeczeństwem, które zdecydowało się go przyjąć jako nowego obywatela, unika ostatecznie losu nomady. Co jednak ważne, podobnie jak nomadzi ci tamilscy uchodźcy w wyniku przemian dokonanych na skutek procesu dekolonizacji utracili swoje ziemie w kraju pochodzenia. Problematyczne jest $\mathrm{w}$ ich przypadku jeszcze określenie tej drugiej cechy - utraty związku z własnym państwem. Większość z moich rozmówców nie utożsamiała się z ideą zniszczonego quasi-państwa Eelam utworzonego przez Tamilskie Tygrysy, ale pomimo, iż utracili oni ochronę państwa lankijskiego, które przestało zaspokajać ich potrzeby jako równoprawnych obywateli, to gdy mówią o ewentualnych powrocie, to nie wyrażają chęci przywrócenia Eelamu, ale pragnienie życia w państwie Sri Lanka na równych prawach, nie będąc jednak spychani na margines życia publicznego jako mniejszość etniczna przy ograniczonych szansach życiowego rozwoju. Co jednak łączy ich z innymi przymusowymi migrantami to fakt, że ich sytuacja jest „jednym z brutalnych przejawów kapitalizmu”. Podobnie jak w pierwszej fazie przemian kapitalistycznych ludzie zmuszeni byli przenosić się do miast, by podjąć jedyną dostępną dla nich pracę, tak uchodźcy ekonomiczni/wojenni 
i polityczni opuszczali kraj w poszukiwaniu możliwości przeżycia, czy też „lepszego życia”, w którym nie będą poddawani nieustannej dyskryminacji. Również pojęcia nomadyzmu i diasporyczności pokrywają się w tym sensie, że oba są wiązane w dyskursie publicznym z działalnością terrorystyczną. Należy odnieść się do osobistych narracji osób doświadczających tych zdarzeń społecznych, aby wytłumaczyć ich możliwy związek.

\section{Fazy życia uchodźcy/uchodźczyni}

Jedną z możliwych strategii badawczych jest wykorzystanie klasycznych koncepcji. W tym przypadku był to model zaczerpnięty $\mathrm{z}$ badań antropologicznych, a mianowicie schemat przechodzenia jednostki przez określone stadia w swoim rozwoju i procesie społecznego funkcjonowania zaproponowany przez Arnolda van Gennepa.

Otóż, istotą koncepcji rytuałów przejścia van Gennepa jest założenie, że każde społeczeństwo składa się z mniejszych społeczności a jednostki w trakcie swojego życia przemieszczają się pomiędzy nimi (Teodorczyk, 2014). Zmiana dokonywać się może na różnych poziomach struktury społecznej, niemniej dotyczy każdej dziedziny ludzkiego życia. „Sam fakt istnienia narzuca konieczność sukcesywnego przechodzenia z jednej społeczności do drugiej, z jednej sytuacji społecznej do kolejnej w taki sposób, że życie jednostki staje się serią etapów, których początek i koniec tworzą zamkniętą całość o niezmiennym porządku (...) Jednostka zaś radykalnie się zmienia, ponieważ ma za sobą szereg etapów i granic" (van Gennep, 2006, s. 30), stwierdza francuski etnolog Arnold van Gennep. Może to być zmiana statusu społecznego ze względu na wiek, wejście do określonej grupy zawodowej, zmianę stanu cywilnego, macierzyństwa, ojcostwa, czy też dotyczyć fizycznego przemieszczania się jednostek w przestrzeni. Każda zmiana budzi lęk, ponieważ stanowi wejście w nowy - mniej lub bardziej - nieznany obszar doświadczeń, pod wpływem których jednostka musi skonfrontować się z różnymi, najczęściej trudnymi emocjami. Jednostki by uniknąć destabilizacji jaźni, a w efekcie również i społeczności muszą sobie radzić z tym lękiem.

Van Gennep opisał społeczne mechanizmy, które to umożliwiają w wydanej 1909 roku książce Obrzędy przejścia. Systematyczne studium ceremonii. Ten francuskiego etnografa i folklorystę, który w duchu swoich czasów posługiwał się pewnymi stałymi toposami etnograficznymi i biologistycznymi metaforami, interesowały przede wszystkim rytuały plemienne jako „narzędzia podtrzymywania ciągłości doświadczenia”. Joanna TokarskaBakir przedstawia ten mechanizm jako „celebrowanie transcendencji całości nad częścią" (Tokarska-Bakir, 2006, s. 9, 13). Uznałam tę koncepcję za przy- 
datną $\mathrm{w}$ analizie procesu zachowania więzi jednostki - uchodźcy - ze wspólnotą, z której została wyrwana - wspólnoty narodowej w kraju pochodzenia w sytuacji przechodzenis do nowego typu ładu społecznego.

Początkowo spodziewałam się, że uda się wyodrębnić jakieś specyficzne sposoby radzenia sobie jednostek $\mathrm{z}$ tym doświadczeniem, jednak zgromadzony materiał nie wskazuje na istnienie takiego uniwersalnego schematu. Van Gennepowska definicja faz życia jednostki posłużyła mi jednak do wyszczególnienia analogicznych faz w życiu uchodźcy. Te z kolei stały się podstawą struktury wywiadu. Przedstawia się ona następująco:

- Faza wyłączenia odnosi się do doświadczeń, które sprawiły, że dana osoba stała się uchodźcą, a więc została wyłączona spod opieki państwa Sri Lanki.

- Faza liminalna to etap podróży - najczęściej dramatyczny i wprowadzający jednostkę fizycznie i psychicznie w nowe obszary doświadczenia. Przedłuża się ona na okres trwania procedury uzyskiwania azylu, a więc pobyt w obozie dla uchodźców (trwający często kilka, a nawet kilkanaście lat).

- Faza włączenia jest z kolei momentem, w którym uchodźca uzyskuje azyl lub pozwolenie na stały pobyt na terenie państwa przyjmującego. Rozpoczyna się wtedy proces asymilacji. Uchodźca powoli włączany jest w struktury nowego państwa, najpierw prawnie, a potem społecznie przez edukację i podjęcie pracy.

Pierwsze postawione przez mnie pytania dotyczyły tego, jak badani Tamilowie postrzegają się nawzajem, jaki jest ich stosunek do Tamilskich Tygrysów, które teoretycznie występowały w obronie ich „interesu narodowego”, oraz czy coś uległo zmianie wich postrzeganiu sytuacji konfliktu syngaleskotamilskiego. W dalszej kolejności interesowało mnie to, czego na temat przyczyn i skutków konfliktu można dowiedzieć się z osobistych narracji osób, które opuściły kraj oraz jak w ich pamięci wyznaczane są granice etniczne grupy własnej. By tego dokonać konieczne było posłużenie się koncepcją tożsamości, która w moim przekonaniu obejmuje swym zakresem wymienione elementy. Za najużyteczniejszą analitycznie definicję uznaję tę zaproponowaną przez Bronisława Misztala, który zwraca uwagę na jej dwie podstawowe składowe, które ilustruje rysunek 1. 


\section{Tożsamość tamilska}

Bronisław Miształ wyróżnia dwa elementy kategorii tożsamości. Zostały one przedstawione na rysunku 1.

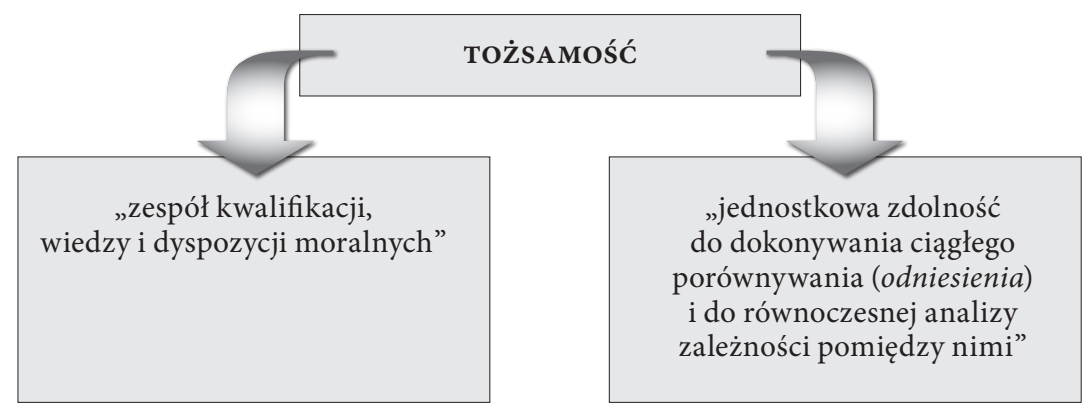

\section{Rysunek 1. Elementy pojęcia tożsamości według B. Misztala}

Opracowanie własne na podstawie definicji B. Misztala (2005, s. 25)

Te dwa elementy pojęcia tożsamości znalazły również swoje odzwierciedlenie w strukturze klucza kategoryzacyjnego, który zawiera w sobie wskaźniki - na poziomie jednostkowym i zbiorowym - definiujące w ogólności mentalny schemat wyobrażeń na temat siebie, grupy własnej i obcych podzielany przez interesującą mnie grupę Tamilów ze Sri Lanki. Warto podkreślić, że w jego skład wchodzą trzy typy odniesień:

1. Odniesienia poznawcze.

2. Odniesienia polityczne.

3. Odniesienia moralne.

W pierwszej kolejności celem badania było opisanie trajektorii życia badanych oraz odkrycie różnorodności ich przeżyć w ramach van Gennepowskiego schematu cyklu przejścia, na podstawie którego możliwe byłoby przedstawienie całościowego obrazu tożsamości Tamilów ze Sri Lanki, którzy zamieszkali w Holandii lub o taką możliwość się starają. Poniżej przedstawiam pytania ogólne i szczegółowe, który wyłoniły się na etapie operacjonalizacji pojęć tożsamości, etniczności i mniejszym stopniu nacjonalizmu odniesionych do historii życia tamilskich uchodźców i emigrantów ze Sri Lanki. Półustrukturyzowany wywiad miał budowę trójczłonową, opracowaną na podstawie koncepcji rytuałów przejścia Arnolda van Gennepa. Na etapie analizy kierowałam się zasadą realizmu transcendentalnego, której celem było 
odkrycie regularności, rozpoznanie i kategoryzacja wyszczególnionych elementów oraz zbadanie związków między nimi. Jednym z modeli klasyfikacji i organizacji analizy narracyjnej jest ujęcie 'kategoria-treść' (Lieblich, TuvalMashiach i Zilber, 1998, s. 12-17). Kategorie w obrębie analizowanego problemu zostają zdefiniowane, a z narracji wyłania się konkretne jednostki tekstu, które następnie grupuje się w określone klasy lub grupy kategorii. Wybrane przeze mnie kategorie były stosunkowo szerokie, i wszystkie fragmenty narracji, które dotyczyły tych zagadnień zostały zebrane w wiązki określone w ramach klucza kategoryzacyjnego. Postępując zgodnie ze wskazówkami do analizy wywiadów narracyjnych Kai Kazimierskiej, na etapie analitycznej abstrakcji wyłaniałam w obrębie kolejnych zapisów z wywiadów kategorie swoiste dla aktualnie analizowanej narracji tworząc w ten sposób przypadek kontrastowy. Następnie porównywałam tak wygenerowane z poprzedniego tekstu kategorie z kolejnymi narracjami. Dzięki temu możliwe było opisanie teoretycznej różnorodności badanego pola. Istotą takiego porównania kontrastowego był „ogląd empirycznie ugruntowanych i sprawdzonych wymiarów, zespołów cech, zbiorów możliwości określających badane zjawisko" (Kazimierska, 2004, s. 86-87). Zgodnie z założeniem, każdy nowy przypadek dostarczał nowych kategorii, aż do momentu teoretycznego nasycenia. $\mathrm{Na}$ bazie tak wyróżnionych podstawowych bloków teoretycznych oraz kategorii swoistych wygenerowałam kategorie ogólne, które stanowią opis podstawowych procesów strukturalnych rzeczywistości społecznej, a więc ostateczny model teoretyczny.

\section{Strategia narracyjna}

Konieczne jest wyjaśnienie zastosowanej przeze mnie strategii narracyjnej. Susan E. Chase stworzyła typologię trzech głosów, czy inaczej strategii narracyjnych wykorzystywanych dziś przez badaczy, gdy przedstawiają narracje uzyskane w czasie wywiadów. Zarówno sposób, w jaki badacz wsłuchuje się w głos narratora podczas wywiadu, tak i w trakcie jego interpretacji, a już szczególnie $w$ momencie jego przedstawiania $w$ ostatecznym raporcie z badania, zależy od przyjętej strategii analitycznej, a ta z kolei uwikłana jest w struktury władzy i interpretacji (Chase, 2009, s. 31-36). Chase opisuje autorytatywny, pomocniczy oraz interakcyjny głos badacza. Wybrany przeze mnie sposób przedstawienia historii narratorów balansuje pomiędzy strategią pomocniczego głosu badacza, który daje możliwość udostępnienia usłyszanych historii szerszej publiczności oraz jego wersji interakcyjnej.

Spośród wielu osób, które podzieliły się ze mną swoim doświadczeniem, trzech miało bliski kontakt i podejmowało jakiś rodzaj współpracy z Tamil- 
skimi Tygrysami, a nacjonalistyczne pozycje były naturalne $\mathrm{w}$ ich otoczeniu. Nilangan, Eniyan i Neelan, należeli do klasy średniej, jak sami się określali, w którą to przede wszystkim uderzył zmieniający się porządek społeczny. Mniej uprzywilejowana część społeczeństwa odczuła ten problem dużo później, stając się obiektem bezpośrednich ataków. Do tego czasu, ich perspektywy życiowe i tak były ograniczone. Zawsze znajdowali się oni w potrzasku między rywalizującymi partiami. Gdy pojawiły się aspiracje narodowowyzwoleńcze tamilskiej klasy średniej, skutki konfliktu początkowo jedynie politycznego, zaczęły dotykać również resztę społeczeństwa. $Z$ uwagi na ograniczenia formalne zwykłego artykułu naukowego, przedstawię tu tylko jedną z wielu ważnych z persektywy badanego problemu opowieść. Głos Neelana odzwierciedla jednak wyzwania, z jakimi spotykała się większość moich Rozmówczyń i Rozmówców:

\section{(Pierwsze spotkanie)}

Do Holandii przyjechałem w 1995 [opowiadał mi Neelan]. Miałem tutaj kontakt, ludzi, których mogłem poprosić o zorganizowanie noclegu. Znałem ich wcześniej. Przyjechałem mając 27 albo 28 lat, ale nie przyjechałem tutaj bezpośrednio. Najpierw byłem w Szwajcarii. Byłem tam przez 3 lata. Potem przeniosłem się tutaj. Tutaj też zajmowałem się pracą polityczną. Tam nie czułem się do końca dobrze. Początkowo zostałem umieszczony w nieczynnym obozie wojskowym. Spędziłem tam 3 miesiące. To było na południu, około 20 kilometrów od granicy z Belgią. Ze Sri Lanki przeniosłem się do Szwajcarii, ze Szwajcarii - do Holandii I od tego czasu żyję tutaj.

Zostałem umieszczony w tymczasowym obozie [kontynuował spokojnie]. Otrzymanie azylu może trwać miesiące, a może trwać też lata - nie ma limitu czasowego. Czasem otrzymuje się decyzję odmowną - wielu ludzi nie upomina się o przyspieszenie spraw. Boją się odpowiedzi negatywnej. Dostają azyl, ale podczas rozmów umieszczani są w obozach tymczasowych. Byłem w 4 albo 5 obozach. Łącznie przez 4 lata. Ostatni z nich to właściwie nie był obóz, tylko ośrodek. Szukali osób ubiegających się o azyl, które mogą się uczyć. Próbowałem studiować administrację biznesową. Skończyłem jeden semestr w Groningen. Było bardzo ciężko. Studia były po angielsku. Z Groningen przeniosłem się tutaj. Tut też studiowałem tylko jeden semestr. Też było ciężko i tym razem zajęcia były po holendersku. Musiałem się uczyć holenderskiego, chodziłem też na kurs. Byłem wtedy nowy w tym kraju. Nie skończyłem administracji. Studia kosztują - pewna organizacja refundowała edukację dla ubiegających się o azyl (University Assistant Fund w Utrecht). Zacząłem studiować, ale nie miałem żadnego konkretnego planu. Moi rodzice chcieli, żebym został lekarzem. Rodzice często oczekują, że ich dzieci będą lekarzami albo inżynierami - to norma w rodzinach klasy średniej [na Sri Lance - przyp. K.D.]. Chodzi o prestiż - jeśli idziesz na studia, to musisz uczyć się na lekarza albo inżyniera. Ale tu nie miałem szansy, nie miałem wsparcia rodziców. 
Na Sri Lance chodziłem przez trzy lata do szkoły przygotowawczej, po której mógłbym iść na medycynę, ale nie kontynuowałem tego, bo to nie było dla mnie. To było w 1992. Miałem skończyć w 1995. To było w Jaffnie. Ten fakt też wpłynął na nasze życie. Czujesz się reprezentantem klasy średniej, rodzice chcą dla ciebie najlepszych perspektyw na dobre wykształcenie i pracę. To cel rodziców z klasy średniej. Opuściłem szkołę przygotowawczą, bo dla mnie w tym wieku była to zbyt duża presja. Byłem bardzo młody i czułem się naciskany przez rodziców. Mówili, że muszę wybrać te studia, ale potem nie mogli mnie wspierać i musiałem znaleźć własne sposoby, by sobie radzić.

W tych czasach pewne grupy zbrojne rekrutowały ludzi. To były lata 80 . Teraz mam 45 lat, widziałem wszystko kiedy zaczęła się wojna. Nie wierzyłem, że to będzie duża wojna. Wielu młodych ludzi było zainteresowanych tym, żeby zostać bojownikami. Chodziło o bohaterstwo, ale też o uwolnienie się od rodzin. $\mathrm{Z}$ jednej strony - nasze przekonania polityczne pochodziły od naszych rodziców. Mieli problemy z rządem, z tym, że musieli znać syngaleski, żeby dostać rządowe posady i to bardzo na nich wpłynęło. Przez to stracili pracę - nie mówili po syngalesku. Rząd dawał szanse Syngalezom, nie Tamilom. Musieliśmy o wszystko walczyć, żeby zrównać się z Syngalezami - traciliśmy swoje szanse. Oni tego doświadczyli i przez to naciskali na nas - musisz mieć najlepsze stopnie, żeby prześcignąć syngaleskich uczniów, dostać się na uniwersytet i znaleźć dobrą pracę. A wtedy większość takich stanowisk było publicznych. Prawie nie było prywatnych przedsiębiorstw. Jeśli ktoś miał własne, lokalne przedsiębiorstwo, to potrzebował tylko pracowników fizycznych, nie przedstawicieli klasy średniej. Dla klasy średniej jedyną szansą były stanowiska publiczne. Dlatego prowadzili nas, abyśmy podążali tą ścieżką kariery.

Moja aktywność polityczna zaczęła się jeszcze z rodzicami. Brali nas na spotkania polityczne, publiczne - również demonstracje. Byłem bardzo mały, nawet od 5 czy 8 roku życia bywałem na publicznych wiecach. Rodzice byli zwolennikami Tamilskiej Partii Nacjonalistycznej. Mówili, że w takiej sytuacji trzeba ich popierać. To była zwykła partia polityczna. W tamtym czasie nie było jeszcze działań zbrojnych. Tylko polityczne. To były lata 7o. Słyszeliśmy o Tamilskich Tygrysach, ale nikt na nich nie zwracał uwagi. Ludzie uważali, że to organizacja przestępcza. Ogólnie ludzie o nich mówili, ale my, ludzie skoncentrowani na polityce - nie. Po prostu z prasy i radia wiedzieliśmy, że istnieją. Były jakieś strzelaniny z policją i zasadzki na ulicach na osoby związane z polityką. To było w prowincjonalnych miasteczkach, nie w dużych miastach. Policja próbowała ich zwalczać, to była organizacja podziemna. To było może 20 aktywnych członków. Porwania były później. W tamtych czasach nikt ich nie znał. Słyszało się, że ktoś zastrzelił dwóch funkcjonariuszy, a potem ktoś przyznał się: my to zrobiliśmy wimię LTTE [Liberation Tigers of Tamil Eelam - potocznie Tamilskie Tygrysy - przyp. K.D.]- był symbol, emblemat, plakaty.

W tamtych czasach żyłem w Kolombo. Otoczeni byliśmy Syngalezami. Zdarzyły się już dwa razy zamieszki na tle etnicznym przeciwko nam. Czuliśmy, że jesteśmy przez nich uciskani. Sam nie doświadczyłem przemocy ze strony Syngalezów, ale słyszeliśmy historie. Urodziłem się w Jaffnie, ale rodzice mieszkali w Kolombo. Byli z klasy średniej, dostali rządowe posady, więc mieszkaliśmy w Kolombo. Wtedy miało się większe możliwości w Kolombo. Kiedy przenieśliśmy się z powrotem do Jaffny, wtedy było tam jeszcze normalnie. Tylko w Kolombo Tamilowie odczuwali dyskryminację ze strony Syngalezów. W Jaffnie nie 
- tam była większość tamilska, Syngalezów było bardzo mało. Nie więcej niż 100 osób. To Syngalezi byli narażeni na ataki na tle etnicznym. Policja też była tamilska. Może na wysokich stanowiskach byli Syngalezi, ale większość policjantów była pochodzenia tamilskiego. Nawet Tamilskie Tygrysy ścigała tamilska policja. Pracowali dla rządu. Ten zabity policjant też był Tamilem. Tamilskie Tygrysy postrzegały ich jako zdrajców, bo Kolombo to był ich wróg. Cała sytuacja się zmieniała, widziałem to w Jaffnie.

Kiedy opuszczałem kraj, wojna już rozgorzała. To był 1990. Wtedy to już był duży konflikt. Wojna była z powodu ingerencji Indii. Jeszcze przed indyjską misją pokojową wspierali tamilskich bojowników dostawami broni. To były czasy Zimnej Wojny. W 1977 były wybory i wygrała partia prozachodnia. Wcześniej patia rządząca była prosowiecka. Po wyborach rząd był już proamerykański i to wywróciło wszystko do góry nogami w jedną noc. Przejście do otwartej gospodarki. Wcześniej nikt nie miał nawet paszportu, żeby opuścić kraj. Można się było starać o paszport jeśli miało się szansę studiować albo dostać pracę zagranicą, ale w innych przypadkach nie potrzebowało się paszportów. Nie potrzebowało się innych krajów (śmiech). Po tej przemianie łatwo można dostać paszport. Wcześniej było trudno - można było, ale tylko do kilku krajów - do Indii i na Bliski Wschód. Wtedy byłem jeszcze młody, nie myślałem o wyjeździe. Miałem możliwość wyjechać i uczyć się w Europie: Norwegii lub paru innych krajach, ale rodzice mi nie pozwolili, bo byłem jeden i nie chcieli mnie puścić, skoro mogłem zostać. Miałem jedną siostrę, ale zmarła młodo, przed wojną. Miała raka.

Musiałem opuścić kraj przez aktywność w ugrupowaniach militarnych. Nie chodziło o Tamilskie Tygrysy, to było EROS [Eelam Revolutionary Organisation of Students - przyp. K.D.]. To nieporozumienie nazywać ich organizacją studencką. To powinno być ERO, dodali S, żeby łatwiej było wymawiać. Przez to wielu ludzi myślało, że to organizacja studencka. Ale każdy mógł dołączyć. Wtedy było dużo organizacji, może 10 albo 15, ale ta była najbardziej postępowa. Ideologicznie postępowa - marksiści. Była też inna grupa, która twierdziła, że są marksistami, ale tak naprawdę byli lewicującymi nacjonalistami. Trochę marksizmu, trochę nacjonalizmu. Najpierw nacjonalizm, potem marksizm. Dlatego dołączyłem do ERO - miałem dość nacjonalizmu ze strony swoich rodziców. Od nich wiem wszystko o nacjonalizmie, odkąd byłem mały. Tamilski i syngaleski nacjonalizm się zwalczały, ale miały pewne punkty wspólne: każda grupa etniczna z własnym językiem musi mieć swój kraj. Ale to nie jest prawda. Uważam Tamilów za naród - narodowość opiera się na posiadaniu własnego języka, więc nie jest to grupa etniczna. [...] To powinno zostać rozwiązane. To bez znaczenia, czy będzie to przez własne ziemie, czy razem z Syngalezami - nie dbam o to.

W tamtym czasie ERO też domagało się Ilamu, ale to było bardziej ideologiczne niż praktyczne. Wtedy wierzyliśmy, że kiedy wszczynasz rewolucję i walczysz z rządem, zakładasz własne państwo i wtedy jesteś w pełni wolny. Ale nie chodziło o to, żeby być przeciw Syngalezom, tylko o oddzielenie dwóch nacji. Jeśli nam by się udało w tej części kraju, oni by mieli tamtą część kraju dla siebie. To bardziej jak podział - oni są oddzieleni ze swoimi pieniędzmi, są osobnym krajem.

Mieliśmy szkolenie wojskowe razem z LTTE. Oni mieli własną grupę militarną. Szkolenie trwało kilka miesięcy. Ale ja nie byłem żołnierzem. Pracowałem z ludźmi na wsi. Miałem spotykać się z ludźmi i rozmawiać z nimi. Na przykład łapałem kontakt z moimi krewnymi w odległości 10 lub 20 mil w innej wiosce, 
zatrzymywałem się u nich $\mathrm{w}$ domu i rozmawiałem $\mathrm{z}$ ich sąsiadami. Przekazywałem im pomysły na temat Ilamu. Ilam to cel. Przed tym musieliśmy zmobilizować ludzi, zwłaszcza robotników i rolników. Ja pracowałem z pracownikami fizycznymi, bo część z moich krewnych była biedna i pracowała jako robotnicy budowlani i rolnicy. Żyłem z nimi i edukowałem ich, a jeśli ktoś chciał się zrekrutować, to też rekrutowałem. Czasem popadałem w konflikty z rodzicami, bo obwiniali mnie, że zabieram ich synów. Miałem wtedy 17 lat. Wtedy też miałem szkolenie wojskowe. Ale to było w celach samoobrony, każdy musiał przejść szkolenie, bo jeśli przyszedłby czas, że będziemy musieli walczyć, to musieliśmy być gotowi. Jeśli już się decydowało stacjonować w wiosce, to trzeba się było tego trzymać, nie można było wrócić do domu. W przeciwnym przypadku można się było przemieszczać gdzie się chce, przejść szkolenie po prostu dla siebie, nie żeby walczyć, tylko do samoobrony. Mogło się zdarzyć, że zostanie się otoczonym przez policję albo wojsko i wtedy trzeba umieć walczyć. W innych przypadkach nie ma problemu, możesz żyć jak każdy inny.

Potem pracowałem na budowach i na roli, żeby solidaryzować się z ludźmi. Nie musiałem tego robić, rodzice dawali mi pieniądze. Odszedłem ze szkoły. Z jednej strony ganili mnie za to, że nie pracuję, nie uczę się, że jestem bezużyteczny; ale z drugiej strony wspierali mnie finansowo, bo jestem ich synem. Nie mogli nic zrobić, więc wspierali mnie dopóki nie miałem pracy. Mój ojciec był przeciwny komunistom. Spierałem się z nim. Nie miałem dużej wiedzy, ale i tak się kłóciłem. Mimo tego, że nie lubił komunistów, miał w domu prace Marksa, nawet Lenina, Maksima Gorkiego i jedną napisaną przez znanego czechosłowackiego komunistę z czasów II wojny światowej. Mieliśmy dużo literatury w domu. Ojciec pozwalał mi czytać, bo chciał, żebym nauczył się wszystkiego. Uczyłem się o religiach, o hinduizmie, nawet o chrześcijaństwie - mogłem wybierać. Wolał, żebym został hinduistą, bo sam był reformowanym hinduistą. Można tak powiedzieć, bo był przeciwny konserwatywnemu hinduizmowi, ale miał indyjską tożsamość narodową. Chodził do świątyni co piątek, to było jak rytuał, czcił hinduskie bóstwa, znajdował w tym jakąś prawdę. Ale interesował się też chrześcijaństwem, buddyzmem, brał mnie do buddyjskich świątyń, do kościoła.

Niebezpiecznie zaczęło się robić, kiedy przybyły indyjskie siły pokojowe. Wtedy nasza organizacja została rozwiązana, przestała funkcjonować. Była utrzymywana przez Indie. Wszystkie organizacje były. Oni dostarczali broń, oni zapewniali szkolenia, to było jakby robili na Sri Lance kukiełkowe przedstawienie. Utrzymywali dobre stosunki z liderami grup. LTTE spodziewali się z tego jakichś zysków ze strony Indii, ale w końcu zerwali stosunki, bo spodziewali się czegoś więcej. Chcieli być jedynymi reprezentantami Tamilów, nie dopuszczali innych grup do władzy. Uparcie się tego trzymali: tylko my mamy być uznawani, nikt inny. Reszta chciała dostać udział we władzy, w przeciwnym wypadku nie chcieli walczyć.Zrobiło się niebezpiecznie. Kiedy wojska indyjskie wkroczyły, wszyscy strzelali do wszystkich. [...]. Kiedy wojska indyjskie przyjechały do Jaffny jako siły pokojowe wiedzieliśmy, że byliśmy pod okupacją indyjską. Wszędzie, gdzie widzisz same wojska indyjskie, jest to samo: oni są panami, czasem tego nadużywają, nie możesz nic powiedzieć przeciwko nim, bo są wielką potęgą, Indie mówią: wy macie zostać w obozach, my zajmiemy się utrzymywaniem porządku. Wtedy byłem z rodzicami. Przed podpisaniem indyjsko-lankijskiego porozumienia pokojowego, w naszej prowincji była tylko armia lankijska. Po porozumieniu przybyła armia indyjska. Powiedzieli, że armia lankijska ma wracać do baz i nie 
wychylać się. Początkowo ludzie myśleli, że to bardzo dobrze, że armia indyjska będzie na miejscu. Ale my mieliśmy trochę wiedzy politycznej. Wiedzieliśmy, co Indie robiły w Bangladeszu, jak oddzielili Bangladesz od Pakistanu. Ale zwykli ludzie nie znali tych historii. Naiwnie wspierali Indie - myśleli, że jeśli oni są hinduistami i Indusi też są hinduistami, a w indyjskiej armii też są Tamilowie, to będą dla nas mili. Nawet jeśli będą jakieś problemy, to nie będzie pobić, nie będą zabijać. Ludzie nie myśleli, że będzie w ten sposób. LTTE zaczęło walkę z armią indyjską. LTTE są bardzo przebiegli. Doskonale wiedzieli, co się stanie, jeśli podejmą jakieś działania. Jaka będzie reakcja. To był element ich strategii. Mieli w tym swój cel. Na przykład, jeśli podkładają minę przeciwpiechotną na drodze do domów mieszkalnych gdzie mieszka dużo ludzi, wysadzają ją i ginie jakiś wojskowy, to potem armia zastrzeli ludzi z okolicy. To była prowokacja. LTTE to odpowiadało, bardzo to lubili. To było im na rękę. Wiedzieli, że jeśli wojsko zacznie atakować ludność, to ludność zacznie popierać LTTE.

Uciekłem, bo aresztowali wszystkich młodych, od 14 do 40 roku życia - każdego. Jeśli tylko coś się działo w wiosce, wszystkich mężczyzn z rodziny brali do swoich obozów - tylko starcy, dzieci i kobiety zostawali. Tam przesłuchiwali: czy jesteś w LTTE, czy ich wspierasz i inne takie. Ustawiali nas w rzędzie w zamkniętej przestrzeni, przed murem. W murze była dziura i za nią stał zawsze człowiek w masce. To był schwytany członek LTTE, który wskazywał ludzi, którzy z nimi pracowali: towarzyszy, nawet pomocników. Wszystkich musiał wskazać indyjskiej armii. Dwa razy wskazali mnie. Pobili mnie, bo byłem członkiem LTTE - dwa razy ktoś wskazał mnie, że byłem w tym samy obozie, co on. To nie była prawda. Nie zawsze wskazują właściwą osobę. Przez tortury muszą kogoś wskazać w grupie. Kogokolwiek. Więc wskazywali też niewinne osoby. Miałem wiele szczęścia, że dwa razy zostałem aresztowany bardzo blisko mojego domu. W mojej wiosce, blisko niej. Raz mnie aresztowali blisko mojej wioski, a drugi raz w miasteczku, gdzie mieszkali moi krewni. Miałem szczęście, bo znałem ludzi. Mogli mi pomóc. Mówili, że są moimi krewnymi. Niektórzy starsi w wiosce mają pewien wpływ. Jeśli coś powiedzą, to armia indyjska ich posłucha. Szanują starszych. Jeśli ktoś z nich powie: znam go, wiem, że nie jest z LTTE, to wypuszczają. Mieli jakieś wspólne interesy (?). Więc wypuścili mnie, ale to było dwukrotny łut szczęścia. W innej prowincji nie znam nikogo, więc jest niebezpiecznie. Poza tym widziałem przypadki, kiedy ludzie $\mathrm{z}$ innej prowincji byli aresztowani tylko za to, że są z innej prowincji. Można się przemieszczać i podróżować, ale kiedy już cię aresztują, robi się niebezpiecznie. Dużo razy takie rzeczy zdarzały się przy mnie, że aresztowali kogoś tylko dlatego, że w dowodzie tożsamości mieli napisane, że są z innej prowincji. Wypytywali co robią tutaj, dlaczego nie są u siebie. Znam przypadki, że ktoś w takich przypadkach zginął. Wiadome jest, że w grupach bojowników wysyła się ludzi, żeby pracowali winnych prowincjach. Może to dlatego, że gdyby pracowali we własnych wioskach, wśród swoich ludzi, robiliby mniej. To bardziej jak armia, nie ruch polityczny.

Pomyślałem, że robi się niebezpiecznie i może lepiej się przenieść do Kolombo. Początkowo moi rodzice mi nie pozwalali, bo co prawda mieli wcześniej pracę w Kolombo, ale w tamtym czasie nie mieli tam nikogo, kto mógłby pomóc. Mówili: jak mógłbyś przeżyć w Kolombo, skoro nie znasz tam nikogo. Mieli tam jakichś krewnych, ale nie mieliśmy z nimi kontaktu. Nie ufali sobie nawzajem. Więc pojechałem do Kolombo sam i sam się z nimi skontaktowałem, poprosiłem ich o pomoc. I pomogli mi. Moi rodzice już nie mieli wyboru - mimo że ich nie 
lubili, musieli mi pozwolić, kiedy powiedziałem, że chcę zamieszkać w Kolombo. To był mój wujek, załatwił mi pracę w swojej firmie. Byłem jego osobistym asystentem. On był tam menedżerem. Był w zarządzie, ja byłem asystentem. Ale nie dostawałem dobrej pensji, bo nie byłem oficjalnie pracownikiem firmy. To był państwowy zakład.

Mieszkając w Kolombo widziałem to samo, co wcześniej - na własne oczy widziałem te same problemy - to, co wcześniej działo się na północy, teraz dzieje się na południu. UNP [partia United Liberation Party - konserwatywna partia prokapitalistyczna - przyp. K.D.] robi to samo, co LTTE na północy. Nie widzę między nimi różnicy - LTTE jest właściwie tamilskim UNP, a UNP - syngaleskim LTTE. Pomijając już same idee polityczne - sposoby działania są takie same. Na przykład mówili, że dziś macie zamknąć sklepy w mieście - w Kolombo, bo tam żyłem. Wysyłali wiadomości do właścicieli sklepów, ze jutrzejszego dnia mają zamknąć sklep, żeby protestować przeciw armii. A jak ktoś nie zamknął, to mógł zostać zabity. Byli skuteczni tylko dlatego, że terroryzowali zwykłych ludzi. Na przykład mówili, że państwowe autobusy nie powinny być dopuszczane na ulicy. I ludzie bali się korzystać z państwowych środków transportu. Były prowadzone przez wojskowych. I były darmowe, więc nie trzeba było biletu. Właściwie to naprawdę zabawne. Może i było niebezpiecznie, ale życiem można się cieszyć. Wiedzieliśmy, że czasem gdzieś wybuchła bomba i ginęli ludzie, ale nie przywiązywaliśmy do tego wagi. Myśleliśmy: każdy kiedyś umrze. Żyć trzeba tak, jak się żyje - sedno w tym, żeby cieszyć się życiem.

Ze Sri Lanki po prostu wyjechałem. Musiałem zapłacić. Pieniądze miałem od rodziców. To się może odbyć na dwa sposoby - albo ty znasz kogoś od przemytu ludzi i pytasz go o wyjazd, albo czasem też oni przychodzą do ciebie i pytają, czy chciałbyś jechać do tego czy tamtego kraju. Jeśli chcesz jechać do Austrii, to jest bardzo tanio. Jeśli chcesz jechać do Szwajcarii, to jest drogo. Wielka Brytania jest droższa niż pozostałe państwa w Europie, a najdroższa jest Kanada.

Wyjechałem, bo z jednej strony chciałem być niezależny od rodziców. Byłem od nich potwornie zależny, a nie chciałem tego. Chciałem żyć po swojemu, więc chciałem wyjechać. Za granicą ludzie nie zwracają uwagi na to, co robisz. Jeśli będziesz robić to samo we własnym kraju, to pomyślą, że odniosłeś życiową porażkę, że nie odnosisz sukcesów. Nadal mam kontakt z rodzicami. Wiedzą, co tu robię i nie są z tego zadowoleni, ale oni nie rozumieją wszystkiego. Nawet mimo to, że są wykształceni, czasem myślą jak prości ludzie. Pytają, co robię w Europie. Inni ludzie zarabiają mnóstwo pieniędzy, mają majątki, a ty co robisz? Kiedy im tłumacze, to mi nie wierzą. Kiedy mówię, że czasem mam problemy ze znalezieniem pracy albo że pracując ciężko czasem wydatki są większe niż zarobki, oni w to nie wierzą. Mają pewne wyobrażenie o Europie, jakby wszystko tu było zapewnione. Początkowo nie planowałem za dużo, po prostu chciałem wyjechać zagranicę, nie miało znaczenia gdzie. [...] Przemytnik ludzi zabrał mnie do Szwajcarii. Dałem mu pieniądze, a on powiedział, że za taką sumę może mnie wziąć do Szwajcarii. Najpierw musiałem jechać do Singapuru, bo na lankijskim paszporcie można tam łatwo wyjechać. Zatrzymaliśmy się tam na tydzień. On poszedł do ambasady rumuńskiej i załatwił mi paszport. Pojechaliśmy do Rumunii i kazał mi tam zostać na tydzień, a on zaaranżował przemyt do Szwajcarii. Pewnej nocy przyszedł, wziął mnie do autobusu turystycznego, i powiedział, że jedzie bezpośrednio do Szwajcarii. Musiałem się w nim chować. Można podróżować jak normalny pasażer, tylko przy granicach trzeba się cho- 
wać. Kierowca autobusu wszystkiego pilnował, mówił nam kiedy zbliżaliśmy się do granicy. Wtedy nie wiedziałem, jak będzie wyglądać moje życie. Większość ludzi ma jakieś wyobrażenie, dużo ludzi, których znam jedzie tutaj, żeby połączyć się z powrotem z rodzinami. Ale ja nie miałem tutaj nikogo, z mojej rodziny byłem tutaj pierwszy.

Teraz żyję z drugą żoną. Poznałem ją na Cyprze. Mam tutaj obywatelstwo od 10 lat. To zupełnie inna sytuacja niż 10 lat temu. Niby powinienem się cieszyć, ale czuję, że straciłem 10 lat, żeby dostać papiery i prawa takie, jak normalny obywatel. Do tego czasu czułem się jak ktoś bez ojczyzny. I przez te 1olat, zwłaszcza jak byłem młodszy, czułem jakby moje życie było w ruinie. Żyłem wtedy w obozie, [...] Musiałem zbierać dowody w swojej sprawie, musiałem się kontaktować z moim prawnikiem. Nawet mój prawnik już się irytował, bo ciągle się z nim kontaktowałem. Myślałem o tym co się stanie, jeśli mnie odeślą do mojego kraju. Czułem się bardzo zagrożony. Tęskniłem za Sri Lanką, ale potem dostosowałem się do kraju, w którym byłem. Teraz czuję się tutejszy, ale nie mogę zapomnieć o swoich korzeniach i tego, skąd pochodzę - nawet nie chcę tego zapominać. Ale fakty są takie, że żyję tutaj, a nie na Sri Lance. Teraz to tam byłbym obcy, bo tutaj żyję już długi czas, przywykłem do tutejszego trybu życia. Musiałbym się tam z powrotem przestawić. Ale chciałbym tam pojechać, nawet zamieszkać. To jednak zależy od sytuacji - jeśli mnie tam będą chcieli, to wtedy wrócę. Czuję jednak, że się tu zmieniłem, m.in. przez długi i problemy finansowe. Zdałem sobie sprawę z tej zmiany dostając obywatelstwo. To był czas, żeby zacząć nowe życie, od zera. Byłem sam, musiałem na siebie pracować. To było trochę jak więzienie - trzeba siedzieć w miejscu i pracować, żeby spłacić długi - żyjesz tu i tylko spłacasz swoje długi, dopóki nie umrzesz. Nadal tak się czuję. Nie czuję się tutaj wolny - nie mam na myśli wolności osobistej, ale finansowo wiedzie się nam ciężko. Trzeba pracować całe życie. Można mysleć, że pewnego dnia dostanie się swoją wolność, ale to może za $10 \mathrm{czy} 20$ lat - to trochę jakby być niewolnikiem. Nadal marzę o takiej wolności. Jakbym miał szansę, to od razu opuściłbym ten kraj. Gdyby tylko znalazł się kraj bardziej gościnny, gdzie sytuacja byłaby lepsza, gdzie mógłbym zrobić coś dla ludzi - wtedy tam bym pojechał. Teraz mimo że jestem aktywny głównie w internecie, piszę głównie po tamilsku, bo chcę coś dać tym ludziom. Większość rzeczy, o których piszę, to rzeczy, o których dowiedziałem się tutaj. Na przykład, jeśli tutaj czytam coś w holenderskojęzycznej gazecie, to przepisuję to po tamilsku, żeby informacje dotarły też tam. Normalnie taka informacja docierałaby tylko do wąskiego grona tutaj, w Holandii. Ale gdzie indziej, zwłaszcza w moim kraju, nikt nic nie wie. Myślę, że muszę coś dać mojemu ludowi [my people]. Pisać zacząłem 5 lat temu. Najpierw dla własnej satysfakcji. Zawsze miałem słabość do podróży, do odwiedzania nowych miejsc i krajów. Kiedy dostałem obywatelstwo i poczułem się wolnym człowiekiem, chciałem się nacieszyć tą wolnością i zwiedzić świat. Byłem w wielu krajach, na przykład w Egipcie, Maroko, Włoszech... jeśli się to dobrze rozplanuje, to można to robić niewielkim nakładem środków. Jeśli znajdziesz tanie bilety. Inni ludzie wydają pieniądze na dom, na samochód, ja nie przywiązuję do takich rzeczy wagi.

Po otrzymaniu obywatelstwa pracowałem jako księgowy. Miałem kurs księgowości, pracowałem w szkole w dziale finansów - opłacałem rachunki, większość to była praca w finansach. Żonę spotkałem pod koniec pracy tam, 5 lat temu. A pierwszą żonę poznałem w Indiach. Podróżuję tam. Byłem tam 3 razy. Za 
trzecim razem poznałem ją. Kochałem ją, ale małżeństwo nie było udane, bo też pochodziła z rodziny, gdzie najbardziej liczyły się takie rzeczy, jak kupowanie biżuterii i tym podobne. W Indiach rodziny klasy średniej mają taki zwyczaj, że zbierają biżuterię i złoto. Chcą się pokazać. Nie chciałem tam zostać. Pojechałem do Indii tylko podróżować. Miała przyjechać ze mną, ale ona sobie inaczej wyobrażała małżeństwo. Że co miesiąc będę jej kupował biżuterię. Tutaj żyłem sam. Ona tu przyjechała dwa razy na wakacje - nawet po małżeństwie. Przyjechałem tutaj i powinienem był ją też tu sprowadzić, ale nie zrobiłem tego, bo wiedziałem, że ona się tu będzie o wszystko kłócić. Rozwiedliśmy się po roku. Drugą żonę poznałem na Cyprze, również podczas podróży. Problem w tym, że poznaję tylko panie [ladies] z prostych rodzin, bo ich mentalność i styl życia są inne niż moje. Czerpią pewne rzeczy ze swojego życia rodzinnego, od krewnych, które nie pasują do mojego świata. Nie wracałem wtedy na Sri Lankę z powodu wojny i bałem się, że to będzie niebezpieczne. W przeciwnym razie być może wziąłbym ślub na Sri Lance. Tamilowie są też gdzie indziej, poza Sri Lanką. Ciągle czuję te różnice, również z obecną żoną. Jesteśmy w trakcie rozwodu. Nadal żyjemy w jednym domu, z naszą córką i synem, ale jesteśmy na etapie rozwodu.

Nie wiem, co teraz będę robił. Problem w tym, że to co ja robię, moje zajęcia, to kompletnie nie ich świat. Moje zaangażowanie, zwłaszcza zaangażowanie polityczne, poglądy polityczne, ale ja mam inny punkt widzenia właściwie na każdy aspekt życia, na przykład na filmy - nie oglądam filmów akcji. To bezużyteczne, jakiś nonsens. Interesują mnie filmy o tematyce politycznej. Kobiety, z którymi brałem ślub, są inne. One lubią dramaty i tym podobne - ich świat jest inny. To rodzi konflikty. No i one nie mają pojęcia co ja robię, o mojej działalności politycznej. Mają dziwny sposób myślenia. Nie rozumieją i nachodzą je dziwne myśli o tym, co robię. One wychowały się w innych rodzinach - ja pochodzę z rodziny zaangażowanej politycznie. Mój ojciec też był aktywistą - to dla nas zupełnie normalne angażować się w życie polityczne. $\mathrm{Z}$ ich punktu widzenia to działalność kryminalna. Dla nich to nic nie znaczy.

Moja żona nie mówi po holendersku. Tylko angielski. Mówiąc o działalności kryminalnej miałem na myśli, że kiedy mówię im o tym, dlaczego nie mogę wrócić na Sri Lankę, o moich problemach politycznych, one tego nie rozumieją. Nie wiedzą co to znaczy. Pytają, ale nawet kiedy tłumaczę, one nie rozumieją. Mówimy tym samym językiem, jesteśmy z tego samego kraju, ale się nie rozumiemy. Żeby to zrozumieć, musisz być z tych konkretnych rejonów. Zwłaszcza chodzi o północ. W innym przypadku to jest jak film - oglądasz film akcji, podoba ci się, imponuje ci heroizm i tak dalej, ale nie przywiązujesz do tego wagi w rzeczywistości. Tak samo jest z nimi: mają duży szacunek do LTTE. Ale nie przez ich aktywność polityczną. Imponuje im bohaterstwo. Robią widowiskowe rzeczy - dobrze walczą, sprzeciwiają się armii - bohaterstwo. To jakby oglądać Rambo w akcji. Tak samo jest $\mathrm{z}$ nimi.

Od początku mojego pobytu w Holandii byłem aktywny politycznie, odkąd mnie wysłali do obozu - tam zacząłem. Zacząłem sam. Było spotkanie dla uciekinierów $\mathrm{z}$ terenów wiejskich, to było w sprawie festiwalu, który miał się odbyć w obozie. Napisałem pamflet na temat konfliktu na Sri Lance. Po holendersku - znalazłem osobę, która pomagała uchodźcom i dyktowałem jej po angielsku, a ona tłumaczyła na holenderski. Razem zrobiliśmy pamflet, zrobiliśmy kopie i wręczaliśmy ludziom. Złapali mnie [śmiech]. Pracownicy centrum uchodźców wezwali mnie i poinformowali, że to niedozwolone. Ludzie w większości nawet nie mogli tego 
przeczytać. Część czytała. To była moja jedyna szansa, żeby poinformować świat zewnętrzny. Nie mieliśmy innego sposobu, żeby skontaktować się z okolicznymi ludźmi. Skorzystaliśmy z okazji. Zrobiliśmy też przedstawienie o konflikcie na Sri Lance. Chcieli zakazać też tego przedstawienia. Pracownicy centrum mówili, że jest zbyt upolitycznione. Powiedzieli, że nie wolno w centrum poruszać tematów politycznych. Możesz zajmować się aktywnością kulturalną - nie polityczną. Ostatecznie pozwolili na wystawienie sztuki pod warunkiem pewnych zmian.

Pomagają mi tutaj Holendrzy. Wtedy przestały do mnie docierać listy, były filtrowane. W centrum listy przechodzą przez recepcję. Dopiero obsługa dostarcza informacje do osób, które mają się zgłosić po pocztę do recepcji. To było dziwne, bo po około miesiącu przestałem dostawać pocztę. Skontaktowałem się z przyjaciółmi i mówiłem, że nie dostałem listu, a oni twierdzili, że wysłali go już tydzień wcześniej. Wysłałem list do samego siebie na pobliskiej poczcie. Nawet tego nie dostałem. Kłóciłem się z obsługą, pytałem jak to możliwe, że nie doszedł do mnie nawet własny list. W centrum żyło 10 innych Tamilów. Nie mam już z nimi kontaktu. Po opuszczeniu centrum miałem kontakt tylko $\mathrm{z}$ jednym przyjacielem. Żyje w Wielkiej Brytanii. Sivę [drugi mężczyzna z którym prowadziłam wywiad - KD] poznałem tu, w Amsterdamie. Przez parę dni pracowałem w jego hotelu. To było w okresie Bożego Narodzenia. Wywiązała się luźna pogawędka. Zacząłem coś o polityce - moje poglądy polityczne zawsze są kontrowersyjne. Wielu ludziom się to nie podoba. W hotelu pracowało ze mną wielu Tamilów, ale tylko Siva zareagował pozytywnie na moje poglądy polityczne. Reszta je odrzucała. On wykazał zainteresowanie. Potem rozmawialiśmy jeszcze wiele razy.

Ciągle utrzymuję poglądy polityczne takie, jakie miałem na Sri Lance - tak samo jak miałem 17 lat, jak i teraz. Ale są też rzeczy, których nauczyłem się z doświadczenia. Bycie uchodźcą też daje doświadczenie polityczne. Ludzie nie zdają sobie $\mathrm{z}$ tego sprawy, ale ja to wiem. To coś w rodzaju oświecenia. Po latach doświadczenia zrozumiałem, dlaczego tutaj goszczą uchodźców. Dlaczego musimy tu przyjeżdżać. Nawet mimo że kiedy tu przyjechałem historia była taka sama jak teraz - mówili: musisz wracać. Nie przyjmujemy uchodźców. Zadawałem sobie pytanie: dlaczego w ogóle przyjmują uchodźców? Dlaczego uchodźcy tu przybywają i dlaczego ten rząd daje tymczasowe miejsce zamieszkania, i dlaczego odmawiają, i dlaczego ich odsyłają? Teraz mam już odpowiedź. Pytałem, czemu przyjmują niewielu ludzi i odsyłają całą resztę. Odkryłem, że to jest w interesie rządu. Kiedy ja tu przyjechałem, był nadmiar uchodźców z Bośni. To przez wojnę w Bośni. Kiedy wojna się skończyła, byli wysyłani z powrotem. Ale oni nie chcieli wracać, tam nie mieli życia i tak dalej. I jakiegokolwiek powodu by nie podali, oni tego nie akceptowali. Tak samo z Afganistanem, Irakiem, Somalią. Kiedy Saddam Hussein był u władzy, przyjmowali wszystkich Irakijczyków. A kiedy wkroczyli tam Amerykanie, wysyłali ich z powrotem.

Wyjazd był moją własną decyzją. To się ciągle zdarza jeśli chodzi o uchodźców politycznych. Nawet teraz przyjeżdża tu wielu uchodźców politycznych ze Sri Lanki - jeśli czują zagrożenie, to opuszczają kraj. To osobista decyzja. Ja nie uciekłem przez wojnę, ale z powodów politycznych - nie miałem możliwości pracować w tamtym kraju. Organizacja, której byłem członkiem, została rozwiązana i większość jej członków dołączyła do LTTE. A ja nie chciałem. Wyjeżdżając do Europy nie wiedziałem, że będę tu aktywistą. Przyjechałem z ciekawości świata. Nawet będąc w organizacji promującej marksizm-leninizm, myślałem jak tamilski nacjonalista. Nawet po przyjeździe do Europy dalej tak myślałem. Teraz już 
nie, tylko jak tu przybyłem. Tylko dlatego, że wyemigrowałem, mogłem zwiedzić świat. Mam inną perspektywę. Gdybym dalej żył na Sri Lance, może dalej myślałbym jak nacjonalista. Bo to trochę zamknięte społeczeństwo, wszystko kręci się wokół tamilsko-syngaleskiego konfliktu. Ale kiedy jesteś poza granicami kraju, spotykasz też innych ludzi, inne kultury, wszystko jest inne. Twoje myślenie się zmienia. Zmieniałem się stopniowo. Tak naprawdę zacząłem się zmieniać w Szwajcarii. Tam mają inne procedury w stosunku do uchodźców. Tam kiedy przyjeżdża uchodźca, chcą, żeby pracował. Starającym się o azyl dają pracę. Przeprowadzają wywiady, umieszczają cię w obozie, a po 2-3 miesiącach naciskają, żebyś pracował. To inna strategia. Wychodzą z założenia, że utrzymanie uchodźców kosztuje szwajcarski rząd. Jeśli dasz im pracę, to nie płacisz za nich. Oni sami pracują na siebie. I jeśli tam pracujesz, to płacisz specjalny podatek ściągany od uchodźców. Nie jest ściągany od imigrantów, tylko od uchodźców starających się o azyl. To pokrywa koszty życia w obozie dla uchodźców. Jeśli się tam zatrzymujesz, to naliczają koszty jedzenia i tak dalej. A jeśli już pracujesz, to musisz płacić co miesiąc. Narażasz nas na koszty - musisz to spłacić.

Wyjechałem, bo uważałem, że nadużywają naszej pracy. Nie akceptowali nas jako mieszkańców kraju, nawet w obozie traktowano nas z dystansem. Tutaj jest odrobinę inaczej. Tutaj mogę studiować, są na to specjalne fundusze. Tu przynajmniej mam jakieś szanse. Tam jesteś tylko robotnikiem. Wtedy jeszcze nie było problemów z przenoszeniem się uchodźców z jednego kraju do drugiego. Tam też miałem pewne problemy polityczne - w Szwajcarii. Publikowaliśmy czasopismo po tamilsku. Drukowaliśmy na zwykłych drukarkach. Pracowaliśmy ciężko, żeby wychodziło co miesiąc. Jeśli masz inny punkt widzenia, to łatwo popadniesz w konflikt z nacjonalistycznym postrzeganiem świata Tamilów. A jakieś 90\% Tamilów miało poglądy nacjonalistyczne i wspierali ideologię LTTE. LTTE cieszyło się z ich poparcia: finansowego, politycznego... dla nas to było ciężkie, żeby wybić się z innym punktem widzenia. Na przykład, pisaliśmy nie tylko o tym, co dzieje się na Sri Lance - nie tylko o tamtejszej polityce. Pisaliśmy też o neonazistowskim terrorze w Europie, problemach uchodźców, o procedurach, przez jakie uchodźcy przechodzą w Europie, o tym jak rząd okrada uchodźców i inne takie rzeczy, o których dyskutowaliśmy w redakcji. To czytali normalni Tamilowie. Przynosiliśmy je do tamilskich sklepów, które je rozprowadzały. Sprzedawaliśmy także Tamilom na ulicach. Po kilku miesiącach LTTE uznało, że Tamilowie nie powinni czytać tego czasopisma. Bo postulowaliśmy za dużo wolności. W naszym czasopiśmie było miejsce dla każdego, żeby wyrazić swoje poglądy. Każdy mógł napisać cokolwiek. W tamtym czasie były też inne czasopisma tamilskie, ale one nie dawały takiej swobody. W Szwajcarii było jeszcze jedno czasopismo, dwa czasopisma były z Paryża. To była prasa diaspory. W Wielkiej Brytanii były dwa czasopisma, z Niemiec. Wtedy był napięty czas, ze Sri Lanki napływały wieści o wojnie, atakach na obozy wojskowe, jak bohatersko przebiega walka, bardzo wyidealizowany obraz LTTE i bojowników. Byli jak anioły. Znałem ludzi, którzy całowali zdjęcia bojowników z LTTE i ich przywódcy. To było jak rodzaj zbiorowej histerii. Diaspora miała niewiele doświadczeń samej wojny. To było dla nich jak film akcji. Sympatyzują z jedną stroną i nie myślą o tym, jak tam ludzie cierpią. Ich to nie obchodzi. Większość ludzi, którzy giną na wojnie, również z rąk LTTE, to niższe warstwy społeczeństwa. Klasa pracująca. Nawet jeśli ktoś, kto przyjechał do Europy pochodził z klasy pracującej, tutaj zmieni punkt widzenia. Przestanie się z nimi solidaryzować. Pieniądze ich zmienią. Jeśli 
się czegoś dorobią, to zrobią się egoistyczni. Prawdziwa klasa pracująca na Sri Lance nie ma szansy się dorobić. Nie mają nawet pieniędzy, żeby zmienić miejsce zamieszkania, to trudne. To wewnętrzni uchodźcy. Czasem są ewakuowani przez wojsko, kiedy w okolicy prowadzone są działania wojenne, muszą zostawić domy i udać się w inne miejsce. Żyli dzięki wsparciu Czerwonego Krzyża i innych NGO. Informacje mieliśmy od osobistych informatorów na miejscu. Kontaktowaliśmy się przez telefon, listy. Opowiadali historie i jeśli ktoś przyjeżdżał tutaj, to robiliśmy wywiady. To było proste w obozach dla uchodźców, bo ciągle napływali nowi ludzie. Teraz jest trudniej, bo obozów dla uchodźców jest mniej. Ale był taki czas, kiedy obóz był w każdym mieście. Wielu ludzi przyjeżdżało. Teraz jest inaczej, nawet rząd ogłosił z radością, że napływa mniej uchodźców. To nie tylko przez to, że wojna się skończyła, ale przez zaostrzone prawo imigracyjne. Nie każdy żyjący na Sri Lance chce ją opuszczać.

Teraz sytuacja jest inna. Łatwiej tam żyć. Tylko ludzie zaangażowani politycznie są zagrożeni. To jak dyktatura - rób co chcesz, ale nie mów o polityce. Wtedy masz problem. Jeśli wspierasz LTTE, to cię złapią. Rząd zna szczegóły życia każdego obywatela. Jak w Europie - zbierają informacje o każdym. Nawet wiem, że rząd Sri Lanki monitoruje mojego Facebooka i mojego bloga. Są też Tamilowie, którzy pracują w instytucjach państwowych i wiem to przez nich. Różnica jest taka, że rząd nie bierze nas na poważnie, bo głównym wrogiem są nacjonaliści, a ja nim nie jestem, więc się nie liczę. Większość ludzi nas nie słucha, więc nie ma się czym martwić. Gdyby ludzie zaczęli się nami interesować, to rząd by nas brał na poważnie. My tylko chcemy uświadamiać ludzi poprzez nasze historie. Media masowe nas ignorują - mówię o tamilskich mediach. Mówiąc „my” mam na myśli ludzi myślących postępowo. Niewielu jest takich. Nawet jeśli wypowiadasz się przeciw konfliktom rasowym i nacjonalizmowi, to przechodzi bez echa. Siedzę w Europie, więc mogę sobie pisać co chcę. Mam kontakt z innymi takimi blogerami. Mamy dobrą sieć ludzi z całego świata: Sri Lanka, nawet Jaffna, Indie, z mojego kraju też. Mojego bloga czytają osoby z 50 krajów - Tamilowie, diaspora. Piszę dla wszystkich. Początkowo pisałem dla diaspory, ale teraz piszę dla ludzi na Sri Lance i w Indiach. Oni mi pomagają, drukują to, co napiszę i rozpowszechniają jako pamflety tym, którzy nie mają internetu. Myślę, że mogę czegoś dokonać. Ale to się nie stanie w ciągu roku, to trochę trwa. To nie jest rewolucja z dnia na dzień, na to trzeba czekać. Rewolucja musi przyjść od ludzi, od mas, nie spadnie z nieba. Jestem marksistą, ale nie trockistą. Czytam wszystkich marksistów. Trockiego też czytałem, parę miesięcy sympatyzowałem z trockistami po przyjeździe tutaj. Międzynarodowi socjaliści. Ale mieliśmy trochę różnic ideologicznych. Jestem tutaj częścią międzynarodowej grupy maoistowskiej. Mamy tutaj otwarte spotkania. Dla mnie są właściwie jak socjaldemokraci.

Nie jestem zwolennikiem dogmatyzmu. Znam wielu takich ludzi, ale ja taki nie jestem. Bardzo się zwalczają przez pomniejsze różnice poglądowe, drobnostki. Nie podoba mi się to. Chciałbym zjednoczyć wszystkich ludzi - marksistów, niemarksistów, nawet demokratów, po prostu ich zjednoczyć dla wspólnej sprawy.

\section{(Drugie spotkanie)}

Mój syn ma teraz 4 lata, bardzo dobrze mówi po tamilsku. Nie przymuszam go do mówienia po holendersku. Dla mnie ważne jest, że mówi w języku ojczystym. 
Mimo że czasem on czuje się dziwnie, kiedy ludzie mówią do niego po holendersku. Nie wie, co odpowiedzieć. A jak powtórzę mu to po tamilsku, to odpowiada. Nauczy się. Bardzo dobrze zna holenderski. Ale w rodzinie mówi się po tamilsku. Kiedyś przyszła (konsultantka) i poprosiła go, żeby przyniósł książki, aby mu poczytać. Mamy dla niego książki po tamilsku, angielsku i holendersku. Przyniósł te po holendersku. Wie, które są które. A jeśli ja go proszę, żeby przyniósł książkę, to przyniesie jakąś po tamilsku. Jego mama też jest tamilskiego pochodzenia, ale ona ma swojego rodzaju kompleks. Chodziła do syngaleskiej szkoły i uważa, że lepiej mówić po syngalesku niż tamilsku. Jest w pewien sposób dumna, że mówi po syngalesku. Uczy się też holenderskiego. Ma też kontakty w społeczności tamilskiej. Myślę, że to wywodzi się z tego, że prości ludzie nie zdają sobie sprawy z tego, jaki to problem. Myślą tylko o sobie i korzyściach dla siebie.

To tak samo jak tutaj - Holendrzy mają większe szanse, żeby znaleźć pracę, więc musisz uczyć się holenderskiego. To wszystko po to, żeby na tym zyskać. Czują wyższość, kiedy mówią tym językiem. Ale nie zdają sobie sprawy, że to tylko język. To tylko środek komunikacji. To jeszcze nie wiedza. Inteligencja, zasób wiedzy, to zupełnie inna sprawa niż język. Wiedzę możesz zdobywać w dowolnym języku, nieważne czy mówisz po holendersku, angielsku, polsku czy tamilsku, to nie gra roli. Uczysz się tej samej rzeczy, uzyskujesz tę samą wiedzę. Oni sobie z tego nie zdają sprawy. Myślą, że jak będą władali językiem płynnie: czy to syngaleski, czy holenderskim, czy angielski, to automatycznie są mądrzy. To nie ma nic wspólnego. Często miewamy z żoną kłótnie, bo ona mówi po syngalesku i angielsku. To przez jej rodzinę, oni oczekiwali, żeby się uczyć języków, bo to ważne. I ona sobie teraz myśli: mówię po angielsku, więc jestem najmądrzejsza na świecie. To problem, bo patrzą po swojej społeczności i porównując ją z inną społecznością widzą, że tamci mają większe przywileje - myślą więc, że jeśli zmienią swoją tożsamość i staną się tacy jak oni, to będą lepsi. Moja żona reprezentuje to romantyczne podejście tamilskich nacjonalistów. Nawet mimo to, że wychowywała się wśród Syngalezów, płynnie mówi po syngalesku, ma taką mentalność - świadomość, że Syngalezi i Tamilowie są osobnymi społecznościami. To idealizowanie tamilskiej tożsamości przyszło później, to dopiero w ostatnich latach. Wcześniej przez 30-40 lat nie było takiego podejścia. A to poczucie wyższości z powodu znajomości angielskiego, to pochodzi z czasów kolonialnych. Jak byliśmy kolonią brytyjską, to myśleliśmy, że mówienie po angielsku znaczy, że jest się lepszym od innych. A potem kraj stał się syngaleski, więc myśleliśmy, że mówienie po syngalesku oznacza wyższość. I wtedy pojawiło się LTTE i zaczęli walkę o niepodległość. To oni zapoczątkowali postrzeganie tamilskiego nacjonalizmu jako czegoś namiętnego. Teraz nawet w Indiach, w Tamilnadu, ludzie deklarują się jako tamilscy nacjonaliści, bo jest w tym ładunek pasji. Jeśli jesteś tamilskim nacjonalistą, to ludzie będą cię postrzegać jako jakiegoś intelektualistę - mimo że oni nie mają jakiejś wyjątkowej wiedzy. Jeśli ich spytać o to, co rozumieją przez 'tamilski nacjonalizm', to nie potrafią tego określić. Mówią tylko: tak, Tamilowie powinni być niepodlegli, mieć swój kraj, nie mają swojego kraju, a każdy naród musi mieć swój kraj. Ale pytani o to, jak to osiągnąć, nie mają odpowiedzi. I wcale się tym nie przejmują. Jakiegokolwiek pytania nie zadasz, mówią, że jeśli Tamilowie będą mieć swoje państwo, to problemy same się rozwiążą. Ja tak nie twierdzę. Pytałem ich wiele razy, jest wiele takich problemów. Ja uważam, że nic nie może się zmienić w jedną noc. Problemy trzeba analizować we wspólnocie, szukać rozwiązania. 
Trzeba nad tym pracować. Kiedy rozmawiałem z postępowymi Syngalezami, to oni mówili dokładnie to samo. To, co Tamilowie mówią o Syngalezach, Syngalezi mówią o Tamilach. Rozmawiając z lewicującymi Syngalezami i mówiąc im o tym, co myślą Tamilowie, tak jak mówię teraz tobie, oni mieli podobne poglądy na nacjonalizm - że to dokładnie to samo, co słyszy się wśród Syngalezów. Syngalezi też mają romantyczne postrzeganie swojej narodowości, też mają swoich bohaterów.

Co zabawne, żadna strona nie wie, co myślą ci drudzy. A nawet jak wiedzą, to twierdzą, że to, co druga strona nazywa nacjonalizmem, to rasizm. Czują swoją wyższość, myślą źle o drugiej stronie. Nawet tamilscy intelektualiści. Znałem kilku doktorów mieszkających w Kolombo, oni tez mówili, że to problem w komunikacji. Syngalezi czują się ponad Tamilami. A tamci myślą, że my nie mamy $\mathrm{z}$ wami nic wspólnego - jeśli jesteś syngaleskim nacjonalistą, to jesteś rasistą. I odwrotnie. [...] bo każdy, nawet intelektualiści, myślał kategoriami etnicznymi. Nawet jeśli byli lewicowi, uważali, że rozwiązanie problemu etnicznego to podstawa. Jedni mówili o podziale ziem, inni o systemie federalnym, jeszcze inni nie wiedzieli, co z tym zrobić. Ale wszyscy myśleli w ten sposób - albo jesteś na górze, albo na dole. Ta sama perspektywa etniczna. Albo chcą państwo podzielić, jak Tamilowie, albo chcą jednego zwartego państwa, jak nacjonaliści syngalescy, albo rozwiązanie pośrednie, jak system federalny, ale wszyscy mówili tylko o sprawach etnicznych. I w bogatych rodzinach, i w biednych rodzinach było to samo. To była sprawa najważniejsza i najpilniejsza. Jeśli tego nie rozwiążemy, to nie możemy ruszyć dalej. Myślę, że rząd to wie - jeśli rozwiążą ten problem, wszystko będzie rozwiązane. Dlatego nie chcą tego zrobić. Zdają sobie sprawę, że może być rewolucja, że lewica może mieć większą siłę przebicia. Teraz są słabi, nikt o tym nie myśli. Teraz wszyscy myślą o Syngalezach i Tamilach. O czym by nie rozmawiać, zawsze wychodzą te sprawy etniczne. Zwłaszcza wśród Tamilów. Na południu ludzie niewiele o tym wiedzą i nie interesują się tym. Tam nie zauważają problemu etnicznego, tylko wojnę. Jedynym problemem było LTTE, więc teraz problem jest rozwiązany. Druga strona myśli, że wojna i LTTE nie mają znaczenia, to kryzys etniczny musi zostać zażegnany. To główna sprawa, którą wszyscy muszą zauważyć: rząd, społeczność międzynarodowa, lewe skrzydło. Musi być jakiś kompromis między dwoma społecznościami. Syngalezi nadal myślą, że to tylko wojna była problemem, a teraz żyjemy w pokoju. To [myślenie - przyp. tłum.] musi się zmienić. A ze strony tamilskiej to poczucie, że nie mamy nic do powiedzenia, nic nie dostajemy, nie mamy niczego - taka mentalność też musi zostać zmieniona. Nie zdają sobie sprawy, że mają pewną siłę przebicia. Robimy co w naszej mocy, żeby to sprawić - ja i ludzie mnie podobni. Nie ma nas wielu. Ale teraz widzę pewną zmianę między nami a nacjonalistami. Wcześniej się nami nie przejmowali. Ani o to, co robimy, ani o to, co mówimy. Nawet nie wspominali naszych imion w komunikatach. Nie chcieli ściągać na nas uwagi, mówić ludziom, że tacy ludzie w ogóle istnieją. Ale teraz atakują - mam na myśli ataki słowne - mówią, że lewica to kolaboranci. Lewicowi politycy, którzy współpracują z rządem są pokazywani jako przykład: tak właśnie robią lewicowcy. Więc lewicowcy to też rasiści, zwłaszcza ci wymieniani w mediach. Więc mówione jest: jest partią lewicową i rasistowską. Prowadzą taką propagandę pośród Tamilów. My z nimi debatujemy za pośrednictwem wszystkich mediów, żeby przeforsować kontrargumenty. Czasem to ignorujemy, bo jeśli tak robią, to oznacza, że ludzie za nami podążają. I oni się tego boją. Inaczej nie zwracaliby uwagi. 5 lat temu 
nie zwracali w ogóle. Wiedzieli, że nie możemy nic zrobić, nikt nas nie słucha, może 2-3 osoby. A dlaczego teraz atakują? Bo słucha nas dużo osób. Bo ludzie chcą zmiany. I Tamilowie, i Syngalezi. Czasy się zmieniają i ludzie też. Teraz następuje przemiana i ludzie wiedzą, że muszą znaleźć nową strategię polityczną, inne opcje. I szukają tych opcji. A jak szukają, to trafiają na nas, słuchają nas.

Jak chodzi o mnie, to kontaktuję się ze wszystkimi lewicowymi partiami. Nie ma ich wiele, ja kontaktuję się z 5 czy 6 . To są partie pozaparlamentarne. Nie wezmą też udziału w wyborach. Bojkotują je. Ale nawet jakby brali, to nie zostaliby wybrani. Myślę, że (nazwa partii 27:30) będzie startować. Wybory nic nie zmienią. Parę osób dostanie nowe posady i nowe pensje. To tyle. A następne wybory będą za 5 lat, więc nie będą musieli się przez 5 lat przejmować się ludźmi. Rząd wie, jak kupić ludzi. Im nie zależy. Nawet partii skrajnego nacjonalizmu tamilskiego - im też nie zależy. Bo jak już zostaną wybrani, dostaną swoje pensje i wygodne życie. Teoretycznie zajmują się polityką dla ludzi - ale których ludzi, to już inna sprawa. Większość jest potem zawiedziona - zawsze. Zawsze się czegoś spodziewają, a potem jest tylko frustracja. To dlatego ugrupowania militarne jak LTTE miały siłę przebicia - z frustracji. Czemu ludzie przekonali się do popierania bojowników, czemu byli skłonni cierpieć w czasie wojny? Wojna to wojna, jak wszędzie. Ludzie byli gotowi poświęcać swoje życie - a to z frustracji. LTTE wiedziało, jak wykorzystać prostych ludzi. W naszej wiosce na przykład podkładali miny lądowe i kiedy armia przejeżdżała, to je wysadzali. Armia panikuje, strzelają na oślep i wszyscy cywile giną. Jeśli znajdziesz się w złym momencie na ulicy, w pobliżu, to umierasz. To się zdarzało wiele razy. LTTE umieszczało miny w miejscach, gdzie żyli ludzie, w gęsto zaludnionych okolicach. Dobrze wiedzieli, że wojskowi będą strzelać do ludzi, ale używali tego do propagandy. A w umysłach ludzi zostawało to, jak bardzo złe jest wojsko, bo zabija Tamilów. Chcieli wspierać LTTE.

Ten romantyczny wizerunek pochodzi od LTTE. Na początku byli bardziej zmilitaryzowaną organizacją. Ich lider zawsze cytował słowa Napoleona: działaj lub giń. Uwielbiał Napoleona. Albo coś robisz, albo giniesz w trakcie. I wszystkim, których rekrutowali mówili to: nie powinniście zadawać pytań. To są rozkazy. Macie być posłuszni przywódcy. Co powie dowódca, wy robicie, żadnych pytań. Waszym zadaniem jest działanie. Rekrutowali ich w ten sposób, prali im mózgi. Byli tam inteligentni chłopcy i dziewczęta, ale bali się odzywać, bo jakby się odzywali, to mogliby ich zabić. Zabijanie nie było dla nich problemem, nikt o to nie dbał. Terror to była ich siła - nie było drogi wyjścia. Trzeba było tylko wykonywać rozkazy. Jest plan operacji, operacja jest udana. A ludzie widzą tylko wynik, a nie poświęcenie członków grupy. Jedyny wyznacznik to liczba zabitych wojskowych. Więcej - to się cieszymy. Mniej - to jest nam smutno. Byłem raz u tamilskiej rodziny w Londynie. Chłopak mówił o tym jacy to nie byli skuteczni, zniszczyli obóz armii. Mama mu mówiła: musisz pamiętać, że wszyscy, którzy brali udział w tej operacji, umarli. To byli młodzi ludzie, którzy poświęcili swoje życia. Czy warto poświęcić tak wiele żyć, żeby zaatakować ten obóz? Matka mówiła w ten sposób. Syn odwrotnie - tyle zniszczyli, tylu wojskowych zabili, wielki sukces, wszystko świetnie, super. Nie wiem, jak będzie z moim synem. To zależy od tego, kto go będzie otaczał. Słyszę od niektórych tamilskich rodzin, że mimo iż nie popierają Tygrysów, ich dzieci są skuszone wizerunkiem Tygrysów $\mathrm{i}$ ich walki. To przez to, że to powszechny sposób myślenia w diasporze. To się bierze $\mathrm{z}$ heroizmu - z czczenia LTTE jako bohaterów. Może to kryzys tożsamości 
w diasporze. To jak z moją żoną: urodziła się w Kolombo, żyła w Kolombo, płynnie mówiła po syngalesku, ale ciągle uważa, że jesteśmy odrębni od Syngalezów. Nawet mimo że nigdy nie widziała wojny na północy, w życiu nie widziała Tygrysów, tylko romantyczne wyobrażenia z mediów - potrzebujemy organizacji jak Tygrysy, by walczyła o nasze odrębne państwo i rzeczy tego typu. To samo dzieje się tutaj, w Europie - dzieci, które urodziły i wychowały się tutaj, nawet chodząc do holenderskich szkól, mówiąc płynnie po niderlandzku, uważają, że bycie Tamilem to coś wyjątkowego. Uważają, że potrzebujemy organizacji jak LTTE i własnego państwa, mimo że nigdy tam nawet nie były, nie widziały tego na oczy, nie wiedzą jak to wygląda. Ale nawet one mówią o tamilskim Ilamie. A osoby, które wiele wycierpiały na Sri Lance nie chcą o tym myśleć, mówią: dajcie nam żyć. Nie chcemy wojny, konfliktów, tylko po prostu żyć. To różnica między ludźmi tu i na Sri Lance. To też kwestia klasowa, kwestia bogactwa. Ludzie żyjący tutaj mają wszystko, idealne życia, nie mają na co narzekać - tam są problemy. Ludzie nie mają przyszłości, pieniędzy, nie mają wystarczająco dużo żywności. To zupełnie inne życie. Tutaj ludzie nie zdają sobie sprawy. Tu się myśli: to, czego potrzebują Tamilowie, to tamilski Ilam. I nic więcej. A jak pogadać z ludźmi na Sri Lance, to słyszy się co innego. Mówią: Ilam mógłby być dobry, ale mamy inne rzeczy na głowie. [...]

W kapitalistycznym społeczeństwie każdy ma swoje miejsce do życia, jest zależny od społeczeństwa na wiele sposobów, więc to ważne, żeby mieć swoją własną tożsamość. To samo mają Marokańczycy, Turcy - niezależnie od tego, czy ich tożsamość jest muzułmańska, czy turecka, czy tamilska - to to samo. Sam nie mogę zignorować swojej tamilskiej tożsamości, to byłby absurd. Ale to nie znaczy, że na tym koniec. Nie mogę postrzegać świata tylko przez pryzmat swojej tożsamości. Najpierw muszę myśleć o tym, gdzie żyję, jakie są tutejsze problemy. Również o tym, co mogę zrobić dla swojego kraju ojczystego, bo tam dorastałem, mam tam rodzinę. W moim przypadku czuję, że wydawałem pieniądze ludzi, którzy żyją na Sri Lance. Edukacja była darmowa, a więc finansowana przez podatników. Więc mam wobec nich pewne obowiązki. Dla mnie to dobre w ten sposób ujednoznacznić relacje $z$ nimi. Bo poza tym nie mam zbyt mocnego kontaktu z tamtejszymi krewnymi - tylko ojciec i parę innych osób. Nie czuję tak ścisłego związku z krewnymi jak inni będący tutaj. Pierwsza generacja zawsze czuje więcej bliskości ze względu na krewnych. Wysyłają pieniądze, trzymają kontakt, a przez to czują większą bliskość z samą Sri Lanką. Ja tego nie mam, ale dorastałem tam i używałem pewnych zasobów. Kiedy żyłem w obozie dla azylantów, pomagałem uchodźcom, na przykład mówiąc jak mogą ulepszyć swoje historie, bo oni czasem nie mieli pojęcia o tle politycznym. Douczałem ich na ten temat. Czasem to pomagało, czasem nie. Mówiłem dlaczego w ogóle ten konflikt na Sri Lance się toczy. Czasem uciekali po prostu dlatego, że wokół toczyła się wojna. Wpadali w ogień krzyżowy, znajdowali się w strefie bombardowania lub ostrzału artyleryjskiego, robiło się niebezpiecznie. Rodzice mówili, że oni mogą umrzeć na wojnie, ale niech ich dzieci przeżyją w innym kraju. Takie było nastawienie rodziców. Wiedzieli, że więcej szans ma się tutaj. W kraju wojny nie ma edukacji, pracy, pieniędzy, czegokolwiek. Jest tylko wojna. Niczego innego nie możesz się spodziewać. Nie masz na czym zbudować sobie życia, myśleć o przyszłości. Tutaj możesz. I ja im w tym pomagałem. To powód, dla którego ludzie tu przyjeżdżają. I nawet jeśli mówią z dumą o Tygrysach i Ilamie, nie myślę, żeby mieli dobre życia w takim kraju. Kiedyś czytałem na WikiLeaks, że amerykański ambasador 
stwierdził, że nawet jeśli Tygrysy wywalczą swoje własne państwo, ludzie, którzy ich wspierali nie będą mogli tam żyć. Bo to będzie nie do zniesienia - żyć w takim kraju. Przez ostre działania Tygrysów wobec obywateli. Ludziom mówili tak: jesteśmy tu z tego samego powodu, dla którego państwo potrzebuje armii: żeby was chronić. Wy płacicie podatek, my was bronimy przed agresywną, syngaleską armią. Inaczej was wszystkich pozabijają.

[...]. Wyszedłem z ośrodka dla uchodźców - jestem szczęśliwy.

Jest to opowieść Neelana współtworzona ze mną w momencie, gdy dokonywałam wyboru fragmentów jego opowieści i przekładu z języka angielskiego na język polski. Był to czas przed jego przeprowadzką do kolejnego kraju. I choć to tylko jedna $z$ wielu dróg uchodźczych, to zwraca naszą uwagę na szereg problemów, z jakimi stykają się ci, którzy opuścili kraj pogrążony w wojnie, a przede wszystkim jaką pamięć ze sobą niosą i przekazują kolejnym pokoleniom.

\section{BIBLIOGRAFIA}

Duchaussois, P. (1931). W płomieniach Cejlonu. Poznań: Wydawnictwo OO. Oblatów M.N.

Kaźmierska, K. (2004). Wywiad narracyjny jako jedna z metod w badaniach biograficznych. Przeglą Socjologiczny, 1.

Lieblich A., Tuval-Mashiach, R. i Zilber, T. (1998). Narrative Research: Reading, Analysis, and Interpretation. Applied Social Research Methods, 47.

Chase, S.E. (2009). Kwestie metodologiczne we współczesnym wywiadzie narracyjnym. W: N.K Denzin i Y.S. Lincoln (red.), Metody Badań Jakościowych. Warszawa: PWN.

Misztal, B. (2005). Tożsamość jako pojęcie i zjawisko społeczne w zderzeniu z procesami globalizacji. W: E. Budakowska (red.), Tożsamość bez granic. Współczesne wyzwania. Warszawa: Wydawnictwo Uniwersytetu Warszawskiego.

Mittal, A. (2015). The Long Shadow of War. The Struggle for Justice in Postwar Sri Lanka. Oakland: The Oakland Institute.

Schütze, F. (2012). Analiza biograficzna ugruntowana empirycznie w autobiograficznym wywiadzie narracyjnym. Jak analizować autobiograficzne wywiady narracyjne. W: K. Kaźmierska (red.), Metoda biograficzna w socjologii. Antologia tekstów. Kraków: Nomos.

Sivasupramaniam, V. (200o). History Of The Tamil Diaspora. Tamil Electronic Library. http:// Murugan.Org/Research/Sivasupramaniam.html (dostęp: 1.10.2013).

Szczepański, J. (1971). Metoda biograficzna. W: idem, Odmiany czasu teraźniejszego. Warszawa: KiW.

Teodorczyk, T. (2013). Zastosowanie koncepcji obrzędów przejścia Arnolda van Gennepa do pracy $z$ progiem $w$ psychologii procesu. „Akademia psychologii zorientowanej na proces”, Marzec. http://Akademiapop.Org/Tomasz-Teodorczyk-Zastosowanie-Koncepcji-Obrzedow-Przejscia-Arnolda-Van-Gennepa-Do-Pracy-Z-Progiem-W-Psychologii-Procesu/ (dostęp: 1.01.2014).

Valenta, M. (2010). Refugees' Social Trajectories and Trajectories of the Self. Forum: Qualitative Social Research, 11(2), Art. 5, http://nbn-resolving.de/urn:nbn:de:0114-fqs100256 (dostęp: 1.06.2014).

van Gennep, A. (2006). Obrzędy Przejścia. Systematyczne Studium Ceremonii, tłum. B. Biały. Warszawa: PIW. 
Wierzbicki, Z. (1971). Stan współczesnej monografistyki społeczności lokalnych i możliwości badań przemian społecznych. Z metod badań społeczności lokalnej w stadium przemian. W: B. Gałeski (red.), Zmiany społeczne i postęp techniczny. Ossolineum.

Young, R.J.C. (2012). Postkolonializm. Wprowadzenie, przeł. M. Król. Kraków: Wydawnictwo Uniwersytetu Jagiellońskiego.

\section{SUMMARY}

\section{The Road We Don't Know - The Refugees Stories}

The presented story, which the reader and the reader will find in the text (when I am silent), comes from interviews collected during my research in the Netherlands in 2013. The research problem I chose at that time - the issue of the identity of Tamils from Sri Lanka in the Netherlands - I decided to investigate using a modified version of the biographical method, which is increasingly used in sociological research. Such a model of analysis is common today also in studies on migration processes, and especially in studies on the problem of refugee. Using this method, in the analytical part, I present the refugee life cycle based on the schema of the rituals of passage by Arnold van Gennep. Therefore, I use a model drawn from anthropological research, namely the pattern of individuals going through certain stages in their development and in the process of social functioning. After the first part, where I outline the research methodology and the main theoretical assumptions, I provide a first-person narrative of one of the people who left Sri Lanka, and her life was inextricably intertwined with the local nearly 30 -year civil war.

KEYWORDS: Sri Lanka civil war, biographical method, stages of a refugee's life, narrative strategy 